\title{
PERANCANGAN E CLASS ZERO-VOLTAGE-SWITCHING $\pi 1 b$ RESONANT INVETER FREKUENSI RENDAH DENGAN PEMICUAN IC SG 3524
}

\author{
Romualdy Widiyanto*), Mochammad Facta, dan Agung Warsito \\ Departemen Teknik Elektro, Universitas Diponegoro \\ Jl. Prof. Sudharto, SH, Kampus UNDIP Tembalang, Semarang 50275, Indonesia \\ ${ }^{*}$ Email: ferdinandromualdy@gmail.com
}

\begin{abstract}
Abstrak
Photovoltaic merupakan sumber energi terbarukan yang banyak dikembangkan, namun output dari photovoltaic masih dalam bentuk arus searah (DC). Oleh karena itu, diperlukan perangkat yang bisa mengubah tegangan DC menjadi tegangan arus bolak balik (AC). E class zero-voltage-switching resonant inverter sebagai salah satu konverter DC ke AC akan diimplementasikan. Rangkaian E class zero-voltage-switching resonant inverter dikontrol melalui sinyal analog PWM yang dibangkitkan IC SG3524. Penggunaan ZVS (Zero Voltage Switcing) memiliki tujuan untuk mengurangi kerugian tegangan pada proses switching MOSFET. Rangkaian resonan $\pi 1 \mathrm{~b}$ dirancang dan digunakan untuk memperbaiki bentuk gelombang keluaran dan meningkatkan tegangan keluaran inverter. Percobaan dilakukan dengan variasi beban, duty cycle, dan frekuensi untuk menyelidiki respon E class zero-voltage-switching $\pi 1 \mathrm{~b}$ resonant inverter. Beban berupa lampu pijar 15W, lampu pijar 25W, dan motor induksi satu fasa capacitor run. Dari hasil uji tegangan keluaran didapatkan bahwa nilai tegangan keluaran meningkat dari frekuensi $49 \mathrm{~Hz}$ ke $50 \mathrm{~Hz}$, kemudian nilai tegangan keluaran menurun dari frekuensi $50 \mathrm{~Hz}$ ke $51 \mathrm{~Hz}$. Pada variasi duty cycle, tegangan output meningkat dari duty cycle $10 \%$ ke $50 \%$ dan kemudian tegangan output menurun dari duty cycle 50\% ke 90\%. Frekuensi juga mempengaruhi kecepatan putar motor, seiring dengan meningkatnya frekuensi, kecepatan putaran motor juga meningkat.
\end{abstract}

Kata kunci : E class resonant inverter, ZVS, $\pi 1$ lb resonant, sg3524, photovoltaic

\begin{abstract}
Photovoltaic is a renewable energy source that is widely developed, however the output of photovoltaic is still in a form of direct current (DC). Therefore, a device that can convert DC voltage to alternating current (AC) voltage is needed. E class zero-voltage-switching resonant inverter as one of DC to AC converter is interested to be implemented. The use of zero-voltage-switching has a purpose to reduce the voltage losses in mosfet switching process. The $\pi 1 \mathrm{~b}$ resonant circuit was designed and used to improved the output waveform and increased the output voltage of the inverter. The experiments were carried out by variation of load. The loads were a $15 \mathrm{~W}$ incandescent lamp, $25 \mathrm{~W}$ incandescent lamp, and one phase induction motor capacitor run. From the output voltage test results it was found that the output voltage value increased from the frequency of $49 \mathrm{~Hz}$ to $50 \mathrm{~Hz}$, then decreased from frequency of $50 \mathrm{~Hz}$ to $51 \mathrm{~Hz}$. In the duty cycle variation, the output voltage increased from the $10 \%$ to $50 \%$ and then decreased from the duty cycle $50 \%$ to $90 \%$. Frequency also affect the motor rotation speed, as the frequency rise, the speed of motor rotation also increased.
\end{abstract}

Keywords: E class resonant inverter, ZVS, $\pi 1 b$ resonant, sg3524, photovoltaic

\section{Pendahuluan}

Photovoltaic atau yang sering disebut juga dengan panel surya merupakan salah satu sumber energy terbarukan yang populer dengan beberapa keuntungannya seperti biaya operasioal yang rendah dan ramah lingkungan[1]. Tegangan yang dihasilkan oleh panel surya relatif kecil yaitu $12-20$ volt tergantung dari jumlah sel surya yang ada pada satu modul panel surya. Tegangan yang dihasilkan dari panel suryapun masih searah atau DC, sehingga untuk digunakan dalam peralatan yang membutuhkan sumber AC dibutuhkan inverter yang berfungsi sebagai pengubah sumber searah (DC) menjadi bolak-balik (AC). Salah satu jenis inverter satu fasa yang ada adalah jenis E class zero-voltage-switching resonant inverter. inverter jenis ini adalah inverter paling sederhana yang dikenal sejauh ini[2].

Penelitian mengenai pemanfaatan inverter jenis $E$ class Zero-Voltage-Switching Resonant sudah dilakukan oleh beberapa peneliti luar negeri seperti pada penelitian[3] mengenai pemanfaatan inverter jenis $E$ class single-switch untuk pemanas induksi. Penelitian[4] mengenai inverter jenis E class single-switch untuk Wireless Power Transfer. Penelitian[5] mengenai pemanfaatan inverter jenis $E$ class single-switch untuk suplai lampu fluorescent. Terakhir 
yaitu penelitian[6] mengenai pemanfaatan inverter jenis $E$ class single-switch sebagai pengendali Piezoelectric Ceramic Transducer. Penelitian yang telah dilakukan di atas semuanya menggunakan frekuensi tinggi hingga mencapai mega hertz.

Pada penelitian ini akan dirancang sebuah alat yaitu inverter satu fasa jenis E class Zero-Voltage-Switching Resonant Inverter resonan $\pi 1 \mathrm{~b}$ menggunakan rangkaian pemicuan dengan IC SG 3524 dimana alat tersebut berfungsi untuk mengubah tegangan searah (DC) menjadi bolak-balik (AC). Sumber tegangan DC berasal dari panel surya yang sudah dilengkapi dengan DC-DC Chopper jenis buck yang berfungsi untuk menurunkan tegangan dan menaikkan arus agar dapat mengisi baterai secara optimal. DC-DC Chopper jenis Boost digunakkan untuk menaikkan tegangan sebelum menuju inverter E class Zero-VoltageSwitching Resonant, maka akan dihasilkan tegangan AC dengan frekuensi $50 \mathrm{~Hz}$ yang cukup untuk menyuplai beban 1 fasa. Pengujian dilakukan dengan pengaturan frekuensi pada beban resistif lampu pijar $(15 \mathrm{~W}, 25 \mathrm{~W})$ dan beban motor induksi 1 fasa capacitor run.

\section{Metode}

Gambar 1. merupakan blok diagram perancangan sistem $E$ class zero-voltage-switching $\pi l b$ resonant inverter. Perancangan ini terdiri 2 sistem utama yaitu rangkaian daya dan rangkaian kontrol. Pada rangkaian kontrol terdapat baterai $12 \mathrm{~V}$ 2,3Ah sebagai sumber, rangkaian DC Boost Isolated, rangkaian pemicuan IC SG3524, dan rangkaian driver MOSFET TLP250. Pada rangkaian daya terdapat panel surya, rangkaian buck converter, baterai $12 \mathrm{~V} 7 \mathrm{Ah}$ sebagai sumber, boost converter, E class zerovoltage-switching $\pi l b$ resonant inverter, dan rangkaian resonan paralel.

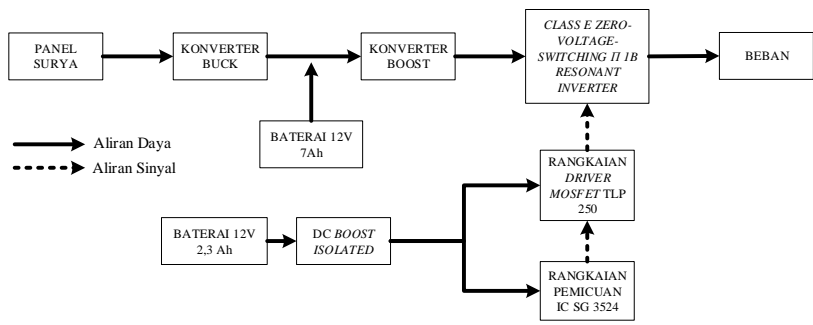

Gambar 1. Blok diagram perancangan

\subsection{Modul Panel Surya}

Modul panel surya yang digunakan adalah tipe monocrystalline. Modul ini dirancang dengan sumber cahaya dihadapkan langsung menghadap panel surya, sehingga cahaya dan panel surya membentuk sudut $90^{\circ}$ [7]. Penelitian dilakukan dalam kondisi panel surya yang berada dalam kotak yang tertutup dengan sumber penyinaran dari lampu halogen 50 watt 220 volt yang dipasang secara paralel. Modul panel surya yang digunakan dalam percobaan dengan spesifikasi sebagai berikut.

Tabel 1. Panel surya pada 1000 watt $/ \mathrm{m}^{2}$ temperatur $25^{\circ} \mathrm{C}$

\begin{tabular}{ll}
\hline Spesifikasi panel surya & Nilai \\
\hline Daya maksimum (W) & 10 watt \\
Tegangan optimal (Vmp) & 18 volt \\
Arus optimal (Imp) & 0.56 ampere \\
Tegangan hubung buka(Voc) & 21.7 volt \\
Arus hubung singkat (Isc) & 0.59 ampere \\
Suhu operasi & $-40^{\circ} \mathrm{C}$ to $+85^{\circ} \mathrm{C}$ \\
\hline
\end{tabular}

\subsection{Baterai $12 \mathrm{~V}$}

Baterai akumulator yang digunakan pada penelitian ini masing-masing memiliki kapasitas sebesar 7Ah dan 2,3Ah. Baterai 7Ah beroperasi secara floating dengan photovoltaic sebagai sumber rangkaian daya, dan aterai 2,3Ah digunakan sebagai sumber untuk rangkaian kontrol.

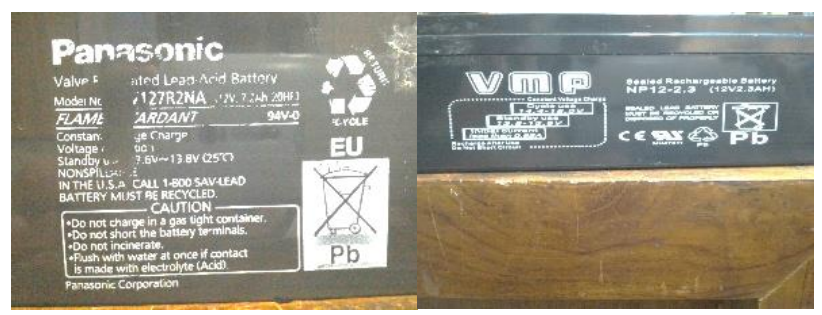

Gambar 2. Baterai 12V

\subsection{Blok Buck Converter}

Rangkaian blok buck konverter menggunakan sumber dari box panel surya dengan tegangan sebesar 20V. Blok buck konverter berfungsi menurunkan tegangan panel surya menjadi sebesar 12,5-13V sehingga baterai dapat bekerja dengan panel surya dalam kondisi floating. Rangkaian blok buck konverter ini terdiri dari modul buck converter yang dilengkapi dengan dioda tipe MUR460 agar tidak terjadi tegangan balik dan pengaman fuse $1 \mathrm{~A}$ untuk mengamankan panel surya.

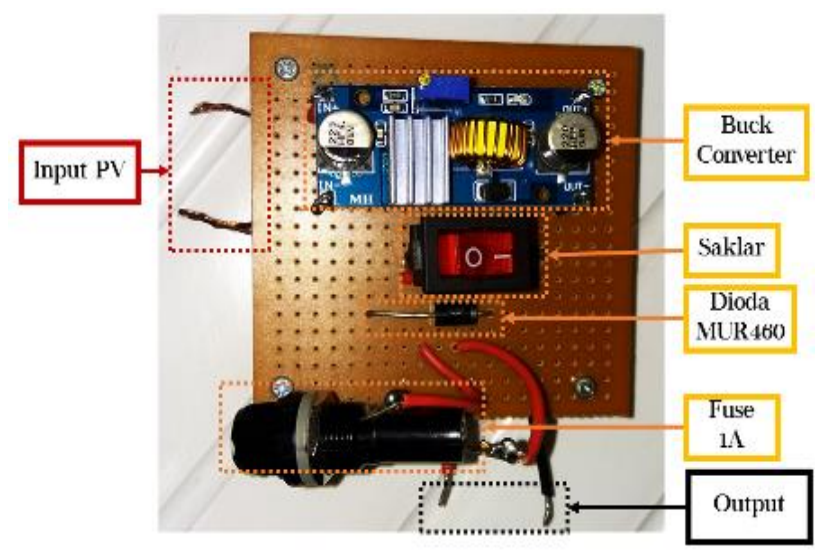

Gambar 3. Rangkaian blok buck converter 
Tabel 2. Parameter Modul Buck Konverter

\begin{tabular}{ll}
\hline Parameter & Nilai Besaran \\
\hline Input Voltage dari panel surya & $20 \mathrm{~V}$ \\
Output Voltage & $12-14 \mathrm{~V}$ \\
Diode MUR460 & $4 \mathrm{~A}, 200-600 \mathrm{~V}$ \\
Modul Buck converter & $5 \mathrm{~A}, 5-35 \mathrm{~V}$ \\
Fuse & $1 \mathrm{~A}$ \\
\hline
\end{tabular}

\subsection{Modul Boost Converter}

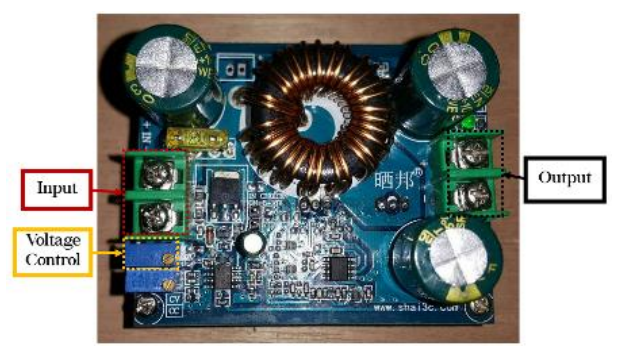

Gambar 4. Modul boost converter

Boost converter pada skema perancangan penelitian digunakan untuk menaikkan level tegangan DC dari baterai. Boost yang digunakan memiliki range input 9$60 \mathrm{Vdc}$ dan range output $12-80 \mathrm{Vdc}$ dengan arus maksimal 12A. Input boost berasal dari baterai, nilai tegangan keluaran boost di-set pada tegangan sekitar $75 \mathrm{~V}$ dengan input baterai pada kisaran 12-12,5V. Kemudian output boost masuk ke blok rangkaian inverter full-bridge. Pada boost juga telah dilengkapi fuse 20A pada input sebagai proteksi short circuit dan over current.

Tabel 3. Parameter Modul Boost Konverter

\begin{tabular}{ll}
\hline Parameter & Nilai Besaran \\
\hline Input Voltage & $9-60 \mathrm{~V}$ \\
Output Voltage & $12-80 \mathrm{~V}$ \\
Input Current Max & $16 \mathrm{~A}$ \\
Output Current Max & $12 \mathrm{~A}$ \\
Conversion Efficiency & $95 \%$ \\
Operating Frequency & $150 \mathrm{kHz}$ \\
Operating Temperature & $-40^{\circ}$ to $85^{\circ} \mathrm{C}$ \\
\hline
\end{tabular}

\subsection{Rangkaian DC Boost Isolated}

Rangkaian DC boost isolated berfungsi untuk membuat ground yang terpisah dari satu sumber DC [8], dikarenakan butuh sumber DC dengan ground terpisah untuk menyuplai IC SG3524 dan keempat IC TLP250 yang digunakan. DC Boost Isolated yang digunakan adalah tipe MORNSUN B1215S-2W.

Tabel 4. Spesifikasi DC Boost Isolated MORNSUN B1215S

\begin{tabular}{ll}
\hline Parameter & Nilai Besaran \\
\hline Input Voltage & $12 \mathrm{~V}$ \\
Output Voltage & $15 \mathrm{~V}$ \\
Supply voltage & $10-35 \mathrm{~V}$ \\
Output Current Operating & $14-133 \mathrm{~mA}$ \\
Temperatur & -400 until $850^{\circ} \mathrm{C}$ \\
\hline
\end{tabular}

\subsection{Rangkaian Daya}

Rangkaian inverter yang dirancang adalah jenis $E$ class zero-voltage-switching $\pi 1 b$ resonant dengan 1 MOSFET sebagai piranti pensaklaran

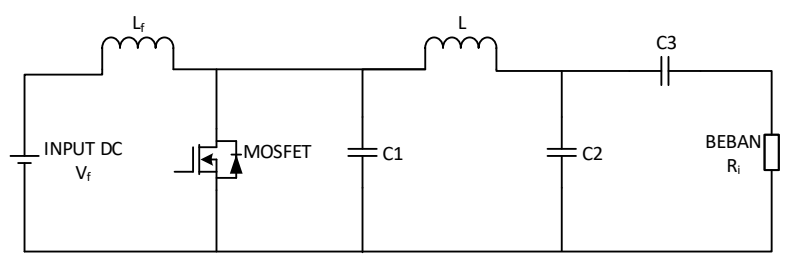

Gambar 5. Rangkaian E class zero-voltage-switching $\pi 1 b$ resonant inverter

Parameter penting yang harus diperhatikan dalam pemilihan komponen MOSFET diantaranya yaitu nilai dari tegangan dan arus kerja MOSFET. Diketahui bahwa nilai tegangan yang bekerja pada MOSFET yaitu $75 \mathrm{~V}$, dan nilai arusnya 4A. Pada penelitian ini digunakan MOSFET tipe IRFP460 sebagai piranti pensaklaran karena spesifikasinya telah memadai.

Parameter yang digunakan untuk mendesain inverter ini adalah :

1. Resistansi full-load $\mathrm{R}_{\mathrm{i}}$ sebesar $7,5 \Omega$.

2. Faktor kualitas rangkaian resonan $\mathrm{Q}_{\mathrm{L}}$ sebesar 7, dari rentang nilai $Q_{L}$ 1-10 dipilih nilai 7 yang memiliki faktor modulasi yang cukup besar, serta aman dalam range resonansi frekuensi.

3. Resistansi suboptimum $\mathrm{R}_{\mathrm{s}}$ sebesar $150 \Omega$, untuk meningkatkan range resistansi kerja inverter $E$ class zero-voltage-switching $\pi 1 b$ resonant.

Resistansi full-load diperoleh dari[2] :

$$
\begin{aligned}
R_{i} & =\frac{8}{\pi^{2}+4} \frac{V_{l}^{2}}{P_{R i}} \\
R_{i} & =\frac{8}{3,14^{2}+4} \frac{75^{2}}{450} \\
R_{i} & =7,2 \Omega \\
R_{i} & \approx 7,5 \Omega
\end{aligned}
$$

Supaya ripple arus pada induktor penahan di bawah $10 \%$ arus masukan DC beban penuh, nilai induktansi penahan harus lebih besar dari[2] :

$$
\begin{aligned}
& L_{f}=2\left(\frac{\pi^{2}}{4}+1\right) \frac{R_{i}}{f} \\
& L_{f}=2\left(\frac{3,14^{2}}{4}+1\right) \frac{7,5}{50} \\
& L_{f}=1,03947 m H \\
& \left.L_{f}=462 m H \text { (diasumsikan cukup ting gi }[2]\right)
\end{aligned}
$$

Nilai kapasitor shunt yang juga merupakan kapasitor ZVS adalah[10] :

$$
\begin{aligned}
C_{1} & =\frac{8}{\pi\left(\pi^{2}+4\right) \omega R_{i}} \\
C_{1} & =\frac{8}{3,14\left(3,14^{2}+4\right) 2 * 3,14 * 50 * 7,5} \\
C_{1} & =78 \mu \mathrm{F}
\end{aligned}
$$

Nilai induktor ZVS dan induktor resonan adalah[10] : 


$$
\begin{aligned}
L & =\frac{Q_{L} R_{i}}{\omega} \\
L & =\frac{7 * 7,5}{2 * 3,14 * 50} \\
L & =167 m H
\end{aligned}
$$

Nilai kapasitor $\mathrm{C}_{2}$ diperoleh dari[2] :

$$
\begin{aligned}
C_{2} & =\frac{1}{\omega R_{i}\left[Q_{L}-\frac{\pi\left(\pi^{2}-4\right)}{16}\right]} \\
C_{2} & =\frac{1}{2 * 3,14 * 50\left[7-\frac{3,14\left(3,14^{2}-4\right)}{16}\right]} \\
C_{2} & =72,58 \mu F
\end{aligned}
$$

Perhitungan kapasitor $\mathrm{C}_{3}$ resonan $\pi \mathrm{lb}$ diperoleh dari[2] :

$$
\begin{aligned}
& X_{C 3}=\frac{1}{\omega C_{3}}=R_{i} \sqrt{\frac{R_{S}\left[\left(Q_{L}-1,1525\right)^{2}+1\right]}{R_{i}}-1} \\
& X_{C 3}=7,5 \sqrt{\frac{\left.150[7-1,1525)^{2}+1\right]}{7,5}-1} \\
& X_{C 3}=198,837 \\
& C_{3}=16 \mu F
\end{aligned}
$$

Sehingga diperoleh nilai - nilai komponen inverter E class zero-voltage-switching $\pi \mathrm{lb}$ resonant sebagai berikut :

$$
\begin{aligned}
& \mathrm{L}_{\mathrm{f}}=462 \mathrm{mH} \quad \mathrm{L}=167 \mathrm{mH} \quad \mathrm{C}_{3}=16 \mu \mathrm{F} \\
& \mathrm{C}_{1}=78 \mu \mathrm{F} \quad \mathrm{C}_{2}=72,58 \mu \mathrm{F}
\end{aligned}
$$

\subsection{Rangkaian Kontrol Pembangkit Sinyal PWM IC SG3524}

Rangkaian kontrol IC SG3524 digunakan untuk menghasilkan sinyal PWM (Pulse Width Modulation). Rangkaian kontrol IC SG3524 dapat mengatur frekuensi dan duty cycle dari gelombang PWM. Nilai frekuensi osilasi pada rangkaian kontrol IC SG3524 diatur oleh dua komponen yang dihubungkan dengan pin 6 dan 7. Pin 6 IC SG3524 adalah Resistor Timer $\left(\mathrm{R}_{\mathrm{T}}\right)$ dan pin 7 IC SG3524 adalah Capacitor Timer $\left(\mathrm{C}_{\mathrm{T}}\right)$. Persamaan untuk mencari frekuensi kerja sesuai pada datasheet IC SG3524 dituliskan oleh Persamaan (7)[10] berikut :

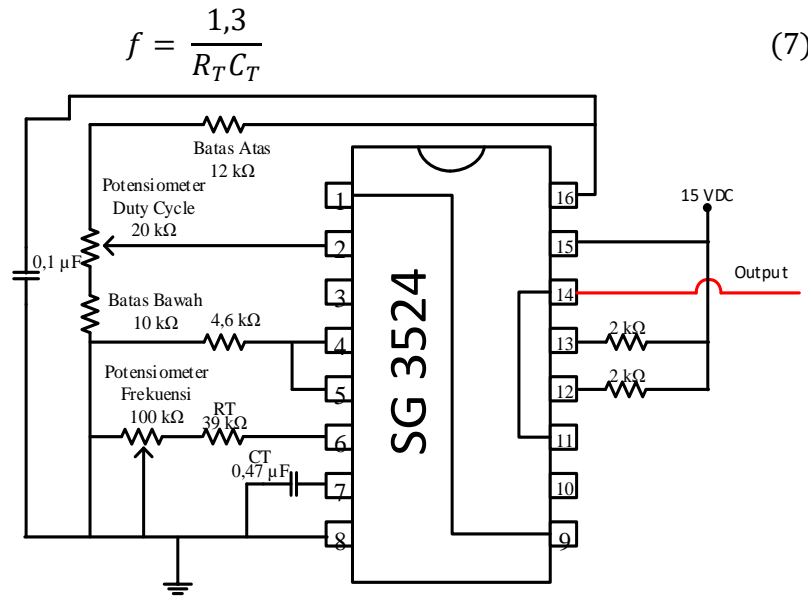

Gambar 6. Rangkaian kontrol IC SG3524
Perancangan output gelombang kotak dapat dilihat pada kaki 11 dan 14 yang dihubungkan, maka keluaran dari IC SG3524 berkonstruksi single-ended untuk mengatur pensaklaran pada $E$ class zero-voltage-switching $\pi l b$ resonant inverter yang hanya menggunakan satu mosfet, single-switch. Rangkaian pemicuan direncanankan mampu beroperasi pada range frekuensi $20 \mathrm{~Hz}-70 \mathrm{~Hz}$.

\subsection{Rangkaian MOSFET Driver IC TLP250}

Rangkaian MOSFET driver menggunakan IC TLP250. Rangkaian TLP250 digunakan untuk mengisolasi dan menguatkan sinyal PWM[11]. Ground antara TLP250 dengan IC SG3524 terpisah sebagai fungsi isolasi antara rangkaian kontrol dan daya.

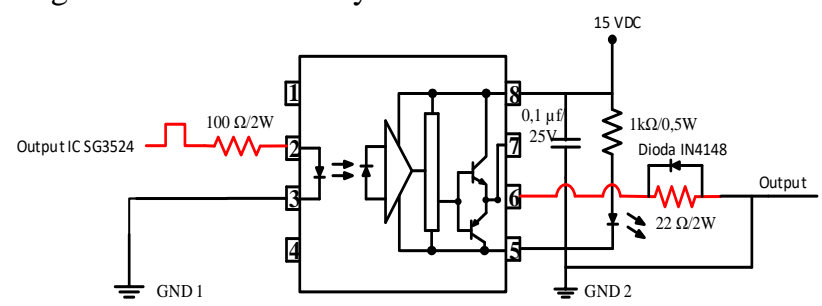

\section{Gambar 7. Rangkaian MOSFET driver TLP250}

Setelah mendapat masukan berupa gelombang kotak keluaran dari IC SG3524, rangkaian MOSFET driver langsung meneruskan gelombang pemicuan tersebut ke rangkaian daya.

\section{Hasil dan Analisa}

\subsection{Pengujian Gelombang Keluaran Rangkaian Kontrol}

\subsubsection{Pengujian Gelombang Keluaran IC SG3524}

Pengukuran rangkaian kontrol pembangkit sinyal PWM dengan IC SG3524 untuk mengetahui bentuk serta karakteristik gelombang pulsa keluaran dari IC SG3524 yang nantinya akan digunakan untuk memicu MOSFET. Pengukuran dilakukan pada kaki 11 dan 14 yang dihubungkan (single ended) yang akan digunakan sebagai masukan pemicuan gate MOSFET. Gambar 4.5 adalah rangkaian pengukuran gelombang keluaran IC SG3524.

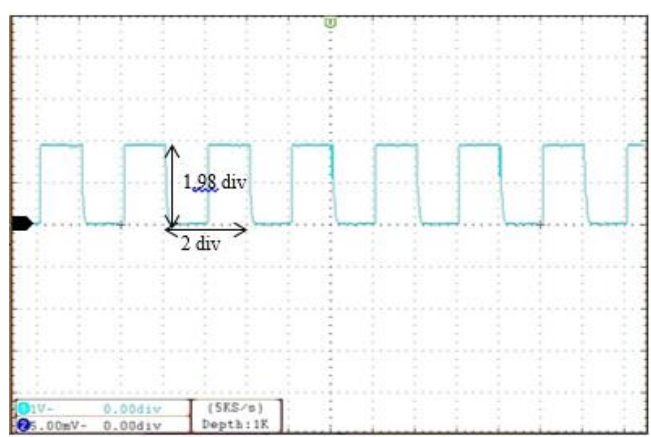

Gambar 8. Gelombang keluaran IC SG3524 
IC SG3524 beroperasi dalam range frekuensi $21 \mathrm{~Hz}-$ $70 \mathrm{~Hz}$. Hasil yang didapat telah mendekati perancangan. Adanya perbedaan antara hasil pengujian dan perancangan dikarenakan adanya efek parasitik pada rangkaian.

\subsubsection{Pengujian Gelombang Keluaran MOSFET Driver TLP250}

Pengujian pada rangkaian ini dilakukan untuk mengetahui dan memastikan gelombang tegangan keluaran dari MOSFET driver TLP250 telah sesuai dengan perancangan dan dapat digunakan untuk pemicuan MOSFET.

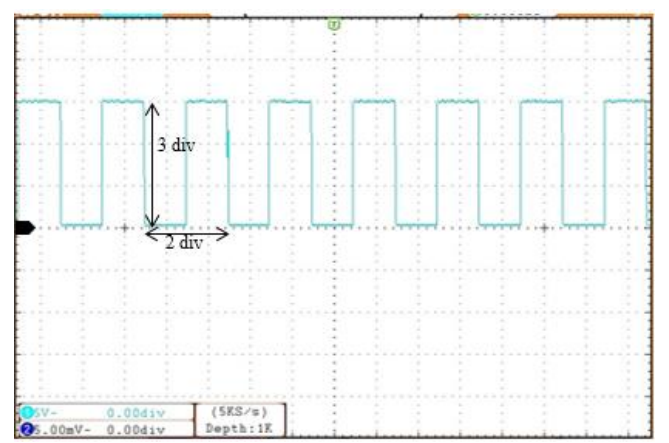

Gambar 9. Gelombang keluaran driver MOSFET TLP250

Hasil pengujian gelombang keluaran dari MOSFET driver TLP250 telah sesuai dengan perancangan dan dapat digunakan untuk memicu MOSFET.

\subsection{Pengujian Gelombang Keluaran E class Zero- Voltage-Switching $\pi 1 b$ Resonant Inverter}

\subsubsection{Pengujian tanpa Beban}

Pengujian ini dilakukan untuk mengetahui bentuk gelombang tegangan keluaran dari rangkaian E class zerovoltage-switching $\pi 1 b$ resonant inverter dalam kondisi tanpa beban.

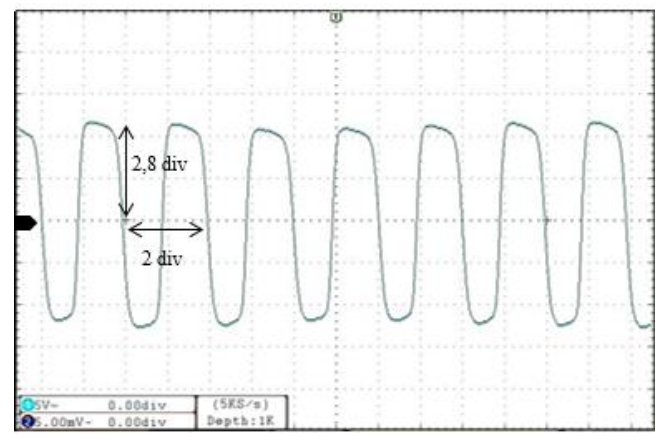

Gambar 10. Gelombang tegangan keluaran $E$ class zerovoltage-switching $\pi 1 b$ resonant inverter tanpa beban

Dari Gambar 10 diketahui bahwa gelombang tegangan keluaran pada frekuensi $50 \mathrm{~Hz}$ dan duty cycle $50 \%$ dari $E$ class zero-voltage-switching $\pi 1 b$ resonant inverter telah mendekati bentuk gelombang sinusoidal, meskipun masih belum sempurna, hal ini disebabkan kurang besarnya nilai induktor pada rangkaian resonan yang menyebabkan bentuk puncak gelombang lebih condong ke arah kiri. Induktor kurang cukup besar untuk menahan lonjakan tegangan saat saklar tiba - tiba ON, sehingga terjadi sedikit peak pada sisi kiri gelombang.

\subsubsection{Pengujian Mode Pensaklaran Zero Voltage Switching (ZVS)}

Pengujian mode pensaklaran dilakukan untuk mengetahui bentuk gelombang keluaran pada komponen kapasitor $\mathrm{C} 1$ dan induktor L pada rangkaian ZVS E class Zero-VoltageSwitching $\pi 1 b$ Resonant Inverter.

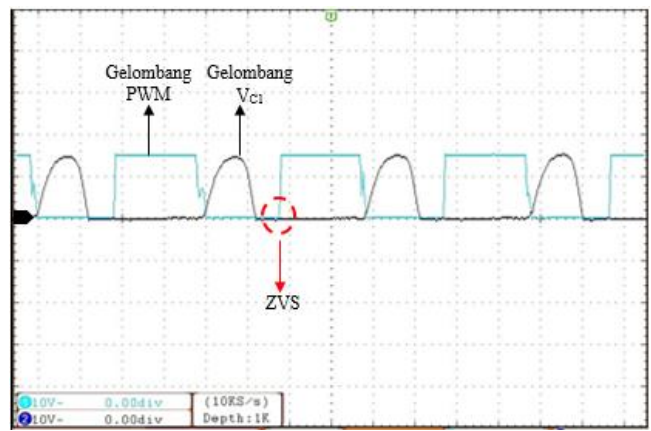

Gambar 11. Gelombang Keluaran $V_{C 1}-$ PWM

Gambar 11 terlihat bahwa tegangan pada kapasitor $\left(\mathrm{C}_{1}\right)$ mengalami kenaikan ketika MOSFET dalam kondisi OFF dan bernilai nol ketika MOSFET dalam kondisi ON, tidak terdapat tegangan yang tersimpan pada kapasitor $C_{1}$ saat MOSFET aktif yang mengakibatkan berkurangnya rugirugi tegangan pensaklaran, dapat disimpulkan bahwa proses zero voltage switching terjadi.

\subsubsection{Pengujian Beban Lampu $15 W(289,25 \Omega)$}

Pengujian ini dilakukan untuk mengetahui bentuk gelombang tegangan keluaran dari rangkaian E class zero - voltage - switching $\pi 1 \mathrm{~b}$ resonant inverter dalam kondisi beban lampu pijar $15 \mathrm{~W}$.

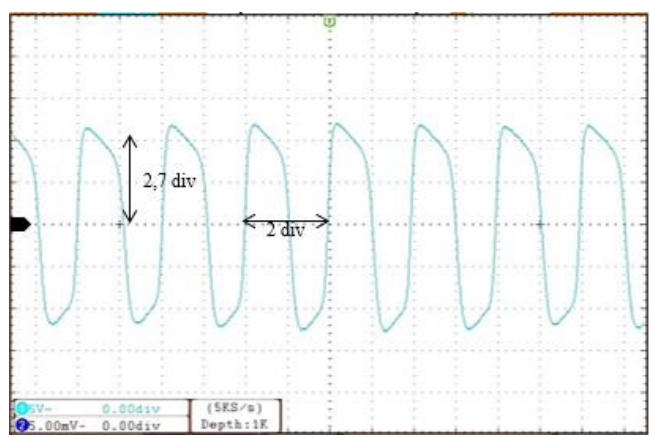

Gambar 12. Gelombang tegangan keluaran $E$ class zerovoltage-switching $\pi 1 b$ resonant inverter lampu pijar 15W 
Dari Gambar 12 diketahui bahwa gelombang tegangan keluaran pada frekuensi $50 \mathrm{~Hz}$ dan duty cycle $50 \%$ dari $E$ class zero-voltage-switching $\pi 1 b$ resonant inverter telah mendekati bentuk gelombang sinusoidal, meskipun masih belum sempurna, hal ini disebabkan kurang besarnya nilai induktor pada rangkaian resonan yang menyebabkan bentuk puncak gelombang lebih condong ke arah kiri. Induktor kurang cukup besar untuk menahan lonjakan tegangan saat saklar tiba - tiba ON, sehingga terjadi sedikit peak pada sisi kiri gelombang.

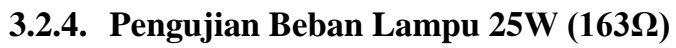

Pengujian ini dilakukan untuk mengetahui bentuk gelombang tegangan keluaran dari rangkaian E class zerovoltage-switching $\pi 1 \mathrm{~b}$ dalam kondisi beban lampu pijar $25 \mathrm{~W}$.

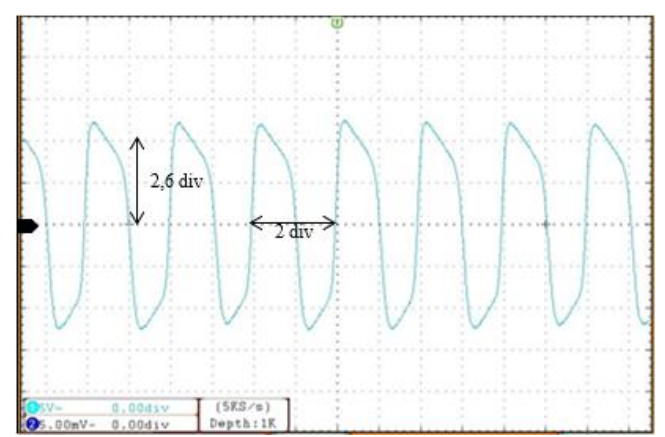

Gambar 13. Gelombang tegangan keluaran E class zerovoltage-switching $\pi 1 b$ resonant inverter lampu pijar 25W

Dari Gambar 13 diketahui bahwa gelombang tegangan keluaran pada frekuensi $50 \mathrm{~Hz}$ dan duty cycle $50 \%$ dari $E$ class zero-voltage-switching $\pi 1 b$ resonant inverter telah mendekati bentuk gelombang sinusoidal, meskipun masih belum sempurna, hal ini disebabkan kurang besarnya nilai induktor pada rangkaian resonan yang menyebabkan bentuk puncak gelombang lebih condong ke arah kiri. Induktor kurang cukup besar untuk menahan lonjakan tegangan saat saklar tiba - tiba ON, sehingga terjadi sedikit peak pada sisi kiri gelombang.

\subsubsection{Pengujian Beban Motor Induksi 1 Fasa Capacitor-Run}

Pengujian ini dilakukan untuk mengetahui bentuk gelombang tegangan keluaran dari rangkaian E class zerovoltage-switching $\pi l b$ dalam kondisi beban motor induksi 1 fasa capacitor run.

Dari Gambar 14 diketahui bahwa gelombang tegangan keluaran pada frekuensi $50 \mathrm{~Hz}$ dan duty cycle $50 \%$ dari $E$ class zero-voltage-switching $\pi 1 b$ resonant inverter telah mendekati bentuk gelombang sinusoidal, meskipun masih belum sempurna, hal ini disebabkan kurang besarnya nilai induktor pada rangkaian resonan yang menyebabkan bentuk puncak gelombang lebih condong ke arah kiri. Induktor kurang cukup besar untuk menahan lonjakan tegangan saat saklar tiba - tiba ON, sehingga terjadi sedikit peak pada sisi kiri gelombang.

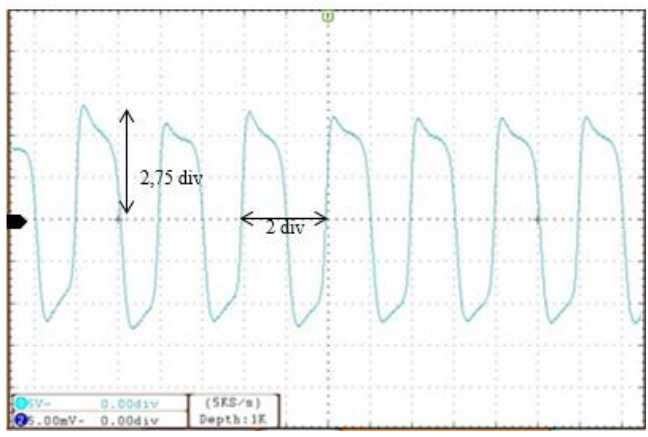

Gambar 14. Gelombang tegangan keluaran E class zerovoltage-switching $\pi l b$ beban motor

3.3. Pengujian Rangkaian E class Zero-VoltageSwitching $\pi 1 b$ Resonant Inverter

3.3.1. Pengujian tegangan keluaran variasi duty cycle dengan frekuensi $50 \mathrm{~Hz}$

Pengujian dilakukan pada frekuensi $50 \mathrm{~Hz}$ dengan variasi duty cycle $10 \%$ - $50 \%$ dengan tingkat kenaikan sebesar $10 \%$. Hasil pengukuran ditunjukkan oleh Tabel 5.

Tabel 5. Hasil pengujian tegangan keluaran variasi duty cycle dengan frekuensi $50 \mathrm{~Hz}$

\begin{tabular}{ccccc}
\hline $\mathbf{n}$ & $\begin{array}{c}\text { Duty Cycle } \\
\mathbf{0}\end{array}$ & $\begin{array}{c}\text { Lampu pijar } \\
\mathbf{1 5 W}\end{array}$ & $\begin{array}{c}\text { Vout }(\mathbf{V}) \\
\text { Lampu Pijar } \\
\mathbf{2 5 W}\end{array}$ & $\begin{array}{c}\text { Motor Induksi } 1 \\
\text { Fasa }\end{array}$ \\
\hline 1 & 10 & 2,6 & 1,6 & 2,8 \\
2 & 20 & 2,9 & 1,8 & 3,1 \\
3 & 30 & 95 & 93,3 & 18 \\
4 & 40 & 95 & 93,4 & 85 \\
5 & 50 & 98,2 & 95,3 & 95 \\
6 & 60 & 97 & 93,4 & 17 \\
7 & 70 & 3 & 2 & 3,4 \\
8 & 80 & 1,6 & 1 & 1,9 \\
9 & 90 & 0,6 & 0,5 & 0,8 \\
\hline
\end{tabular}

Berdasarkan Tabel 5. dapat dilihat bahwa pengujian yang dilakukan sudah sesuai dengan teori dimana pengaruh duty cycle terhadap tegangan keluaran dari E class zero-voltageswitching $\pi 1 b$ resonant inverter adalah ketika duty cycle dinaikkan atau diturunkan maka akan terjadi penurunan tegangan. E class zero-voltage-switching $\pi l b$ resonant inverter memiliki kinerja optimal hanya saat frekuensi $50 \mathrm{~Hz}$ dan duty cycle pensaklaran $50 \%$, ini diakibatkan inverter ini hanya menggunakan satu pensaklaran, single switch[2]. Saat menggunakan beban lampu pijar $15 \mathrm{~W}$ tegangan output terbesar saat pada frekuensi $50 \mathrm{~Hz}$ dan duty cycle pensaklaran $50 \%$ yaitu $98,2 \mathrm{~V}$, saat menggunakan beban lampu pijar $25 \mathrm{~W}$ tegangan output terbesar saat pada frekuensi $50 \mathrm{~Hz}$ dan duty cycle pensaklaran $50 \%$ yaitu $95,3 \mathrm{~V}$, saat menggunakan beban motor induksi 1 fasa 
tegangan output terbesar saat pada frekuensi $50 \mathrm{~Hz}$ dan duty cycle pensaklaran $50 \%$ yaitu $95 \mathrm{~V}$.

\subsubsection{Pengujian kecepatan putar motor variasi frekuensi dengan duty cycle $50 \%$}

Pengujian dilakukan pada duty cycle $50 \%$ dengan variasi frekuensi $49-51 \mathrm{~Hz}$ dengan tingkat kenaikan sebesar $1 \mathrm{~Hz}$. Hasil pengukuran ditunjukkan oleh Tabel 6.

Tabel 6. Hasil pengujian kecepatan putar motor variasi frekuensi dengan duty cycle $\mathbf{5 0 \%}$

\begin{tabular}{ccc}
\hline No. & $\mathbf{f}(\mathbf{H z})$ & $\mathbf{n}(\mathbf{r p m})$ \\
\hline 1 & 49 & 1430 \\
2 & 50 & 1453 \\
3 & 51 & 1493 \\
\hline
\end{tabular}

Berdasarkan Tabel 6. dapat dilihat bahwa pengujian yang dilakukan sudah sesuai dengan teori dimana pengaruh frekuensi terhadap kecepatan putaran motor induksi satu fasa capacitor run adalah semakin besar frekuensi yang digunakan maka kecepatan putar motor induksi satu fasa yang akan dihasilkan akan semakin besar pula.

\subsubsection{Pengujian kecepatan putar motor variasi duty cycle dengan frekuensi $50 \mathrm{~Hz}$}

Pengujian dilakukan pada frekuensi $50 \mathrm{~Hz}$ dengan variasi duty cycle 10-90 \% dengan tingkat kenaikan sebesar $10 \%$. Hasil pengukuran ditunjukkan oleh Tabel 7.

Tabel 7. Hasil pengujian kecepatan putar motor variasi duty cycle dengan frekuensi $50 \mathrm{~Hz}$

\begin{tabular}{cccc}
\hline No. & Duty Cycle (\%) & Vout(V) & n(rpm) \\
\hline 1 & 10 & 2,8 & 0 \\
2 & 20 & 3,1 & 0 \\
3 & 30 & 18 & 162 \\
4 & 40 & 85 & 1119 \\
5 & 50 & 95 & 1453 \\
6 & 60 & 17 & 449 \\
7 & 70 & 3,4 & 0 \\
8 & 80 & 1,9 & 0 \\
9 & 90 & 0,8 & 0 \\
\hline
\end{tabular}

Berdasarkan Tabel 7. dapat dilihat bahwa pengujian yang telah dilakukan sudah sesuai dengan teori dimana pengaruh duty cycle terhadap kecepatan putaran motor induksi satu fasa capacitor run adalah kecepatan putar akan maksimal pada saat $E$ class zero-voltage-switching $\pi l b$ resonant inverter bekerja optimal saat frekuensi $50 \mathrm{~Hz}$ dan duty cycle pensaklaran $50 \%$. Hal ini dikarenakan ketika duty cycle dinaikkan atau diturunkan maka akan terjadi penurunan tegangan. Tegangan memiliki nilai yang cukup untuk menggerakkan motor hanya pada saat duty cycle 30-60\%. Tegangan keluaran maksimal berada saat frekuensi $50 \mathrm{~Hz}$ dan duty cycle pensaklaran 50\%, sehingga kecepatan yang dihasilkan maksimal yaitu sebesar 1453rpm

\subsubsection{Pengujian tegangan keluaran pada variasi pembebanan}

Dari pengujian rangkaian E class zero-voltage-switching $\pi l b$ resonant inverter dengan berbagai variasi pembebanan, dapat dilakukan perbandingan antara frekuensi dengan tegangan output masing - masing pembebanan. Hasil pengukuran ditunjukkan oleh Tabel 8.

Tabel 8. Hasil pengujian variasi frekuensi dan pembebanan pada duty cycle $50 \%$

\begin{tabular}{ccccc}
\hline No & $\begin{array}{c}\mathbf{f} \\
\cdot\end{array}$ & $\begin{array}{c}\text { Vout }(\mathbf{V}) \\
\text { Lampu pijar }\end{array}$ & $\begin{array}{c}\text { Lampu Pijar } \\
\text { 15WW }\end{array}$ & $\begin{array}{c}\text { Motor Induksi 1 } \\
\text { Fasa }\end{array}$ \\
\hline 1 & 49 & 95 & 91,9 & 93,2 \\
2 & 50 & 98,2 & 95,3 & 95 \\
3 & 51 & 96,6 & 93,2 & 94 \\
\hline
\end{tabular}

Berdasarkan Tabel 8. dapat dibuat grafik perbandingan antara frekuensi dengan tegangan keluaran seperti pada Gambar 15.

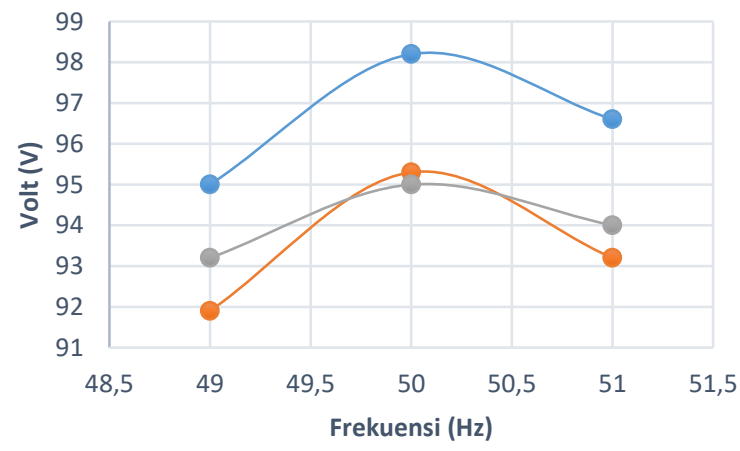

$\longrightarrow$ Lampu Pijar 15W $\longrightarrow$ Lampu Pijar 25W $\longrightarrow$ Motor Induksi 1 Fasa

Gambar 15. Grafik hubungan antara frekuensi dengan tegangan keluaran

Berdasarkan Tabel 8. dan Gambar 15. dapat diketahui bahwa tegangan output tertinggi yaitu pada beban lampu pijar $15 \mathrm{~W}$ dengan tegangan, sedangkan tegangan output terendah pada beban motor induksi 1 fasa. Tegangan output tertinggi yaitu pada beban lampu pijar $15 \mathrm{~W}$ frekuensi $50 \mathrm{~Hz}$ dengan nilai tegangan output $98,2 \mathrm{~V}$, dan tegangan output terendah yaitu pada beban motor induksi 1 fasa frekuensi $50 \mathrm{~Hz}$ dengan nilai tegangan output $95 \mathrm{~V}$. Dari data yang ada dapat diambil kesimpulan bahwa beban mempengaruhi tegangan output dari E class zero-voltageswitching $\pi l b$ resonant inverter. Semakin besar beban yang terhubung, maka nilai tegangan output akan semakin rendah. Berdasarkan teori yang ada, apabila beban yang terhubung pada rangkaian resonan semakin besar maka faktor kualitas dari rangkaian resonan akan menurun, sehingga nilai penguatan tegangan pada rangkaian resonan juga mengalami penurunan.. Hal ini disebabkan karena semakin besar beban maka nilai resistansi akan turun, yang akan menyebabkan terjadinya penurunan tegangan dari 
rangkaian resonan. Hal ini telah sesuai dengan hasil yang didapat dari pengujian karena seiring dengan meningkatnya beban yang terhubung, nilai tegangan output juga mengalami penurunan. Ketiga beban memiliki trend keluaran tegangan yang sama, yaitu memiliki output tegangan maksimal ketika berada pada frekuensi $50 \mathrm{~Hz}$ dan tegangan keluaran akan turun ketika frekuensi diubah lebih besar maupun lebih kecil dari $50 \mathrm{~Hz}$, hal ini sudah sesuai dengan teori output resonan[12], sehingga dapat dikatakan perancangan $E$ class zero-voltage-switching $\pi 1 b$ resonant inverter sudah menghasilkan frekuensi resonan.

\section{Kesimpulan}

Inverter jenis E class zero-voltage-switching $\pi 1 b$ resonant sudah berhasil dibuat dan menghasilkan tegangan keluaran arus bolak-balik, dimana akan menghasilkan tegangan maksimal pada duty cycle 50\% dan frekuensi resonannya, dalam perancangan ini digunakan frekuensi resonan yang rendah yaitu $50 \mathrm{~Hz}$, hal ini dikarenakan inverter jenis $E$ class zero-voltage-switching $\pi 1 b$ resonant bekerja secara optimal pada duty cycle $50 \%$ dan frekuensi $50 \mathrm{~Hz}$. Ketika duty cycle lebih rendah atau lebih tinggi dari 50\% maka akan terjadi penurunan tegangan keluaran dan efisiensi. Perancangan Inverter jenis E class zero-voltage-switching $\pi 1 b$ resonant menggunakan jenis pensaklaran ZVS, pada saat proses pensaklaran tegangan pada kapasitor $\left(\mathrm{C}_{1}\right)$ mengalami kenaikan ketika MOSFET dalam kondisi $O F F$ dan bernilai nol ketika MOSFET dalam kondisi $O N$ sehingga dapat dikatakan bahwa proses zero voltage switching terjadi. Beban lampu pijar $15 \mathrm{~W}, 25 \mathrm{~W}$, dan motor induksi satu fasa capacitor running memiliki trend keluaran tegangan yang sama, yaitu memiliki output tegangan maksimal ketika berada pada frekuensi $50 \mathrm{~Hz}$ dan tegangan keluaran akan turun ketika frekuensi diubah lebih besar maupun lebih kecil dari $50 \mathrm{~Hz}$, dapat dikatakan perancangan $E$ class zero-voltage-switching $\pi l b$ resonant inverter sudah menghasilkan frekuensi resonan. Frekuensi juga berpengaruh terhadap kecepatan putar motor dimana semakin besar nilai frekuensi maka akan semakin besar pula kecepatan putaran motor.

\section{Referensi}

[1]. S. Muhammad, "Pemanfaatan Solar Cell Sebagai Pembangkit Listrik Terbarukan”, J. Tek. Jakarta, vol. 27 Nomor 3, 2014.

[2]. K. K. Marian and D. Czarkowski, "Resonan Power Converter", Second. A John Wiley \& Sons, INC, 2011.

[3]. A. Skala and Z. Waradzyn, "A Single-Switch E class Voltage-Source Inverter For Induction Heating Influence Of The Parameters Of The Resonant Circuit Elements On Its Performance At Optimal Control”, AGH - University of Science and Technology, Krakow, Poland, no. 1, pp. 33-36, 2017.

[4]. S. Aldhaher, P. C. K. Luk Senior Member, and A. Bati, "Wireless Power Transfer Using E class Inverter with Saturable DC-Feed Inductor", IEEE Transactions on Industry Applications, Volume 50 , Issue 4, 2014, Pages 2710 - 2718, 2014.

[5]. B. D. Singer and G. R. Walker, "A E class Resonant Inverter For Use As Electronic Fluorescent Lamp Ballast", Australasian Universities Power Engineering Conference (26-29), September, 2004.

[6]. H. L. Cheng, C. A. Cheng, and C. C. Fang, "SingleSwitch High Power Factor Inverter for Driving Piezoelectric Ceramic Transducer", 1571-1576.

[7]. M. Prasetyawan, A. Nugroho, and M. Facta, "Modul Praktikum Penyinaran Sebagian dan Penuh pada Photovoltaic Jenis Monocristalline," TRANSIENT, vol. 3, no. 3, 2014.

[8]. MORNSUN, "B1512S-2W Datasheet," 2008.

[9]. Z. Salam, M. Facta, and M. Amjad, "Dielectric Barrier Discharge Ozonizer Using the Transformerless SingleSwitch Resonant Converter for Portable Applications," vol. 50, no. 3, pp. 2197-2206, 2014

[10]. Texas Instrument, "SG3524, SG2524 Datasheet," Dallas, Texas, 2003.

[11]. TOSHIBA, "TLP250 Datasheet," 2017.

[12]. N. Utomo, "Perancangan Inverter Jembatan Penuh Dengan Rangkaian Pasif LC Beban Paralel," TRANSIENT, vol. 2, no. 3, pp. 1034-1039, 2013. 